\title{
IMPACT OF SILICON CARBIDE NANOPARTICLES ON HATCHING AND SURVIVAL OF SOIL NEMATODES CAENORHABDITIS ELEGANS AND MELOIDOGYNE INCOGNITA
}

\author{
Al BANNA, L. ${ }^{1 *}-$ SALEM, N. ${ }^{1}-$ GHRAIR, A. M. ${ }^{2}-$ HABASH, S. S. ${ }^{1,3}$ \\ ${ }^{1}$ Department of Plant Protection, School of Agriculture, The University of Jordan \\ Amman, Jordan \\ (phone: +962-777-4247-14) \\ ${ }^{2}$ Royal Scientific Society, Materials Research \& Development/Knowledge Sector \\ Amman, Jordan \\ (phone: +962-6-534-4701) \\ ${ }^{3}$ INRES - Molecular Phytomedicine, Rheinische Friedrich-Wilhelms-University of Bonn \\ Karlrobert-Kreiten-Straße 13, Bonn, Germany \\ (phone: +49-22-873-1670) \\ *Corresponding author \\ e-mail: lalbanna@ju.edu.jo \\ (Received $14^{\text {th }}$ Oct 2017; accepted $3^{\text {rd }}$ Apr 2018)
}

\begin{abstract}
Silicon carbide ( $\mathrm{SiC}$ ) nanoparticles are widely used in industrial applications; however, some reports indicate they are safe while others claim the opposite. We aimed to characterize the physicochemical properties of $\mathrm{SiC}$ nanoparticles and investigate their impact on the multicellular animal model, Caenorhabditis elegans and the plant parasitic nematode Meloidogyne incognita. The X-ray diffractogram patterns and chemical analyses confirmed that the content is $\mathrm{SiC}$. Furthermore, $\mathrm{N}_{2}$ sorption isotherm analyses revealed that Brunauer-Emmett-Teller (BET) surface area was $37.6 \mathrm{~m}^{2} / \mathrm{g}$ and single point adsorption total pores volume of pores less than $126.1853 \mathrm{~nm}$ in diameter at $\mathrm{p} / \mathrm{p}^{\circ}=0.984417366$ was $0.124975 \mathrm{~cm}^{3} / \mathrm{g}$. Furthermore, adsorption average pore width was $13.26382 \mathrm{~nm}$. Scanning electron microscopy showed that the $\mathrm{SiC}$ nanoparticles have a semi-crystalline shape with uncompleted faces. Some edges are angular whereas others are curved and smooth with an average particle size of $50 \mathrm{~nm} \pm 21.5$. The bioassays indicated that $\mathrm{SiC}$ nanoparticles did not affect hatching of larvae of both nematodes, whereas they affected dramatically the survival of the first stage larvae (L1) of C. elegans, but not the second stage juveniles $\mathrm{J}_{2} \mathrm{~S}$ of $M$. incognita. There was no effect of $\mathrm{SiC}$ on length and width of the dead L1; however, internal organs, particularly the intestine, exhibited black color indicating uptake of the SiC nanoparticles.

Keywords: physicochemical properties, toxicity, electron microscopy, X-ray
\end{abstract}

\section{Introduction}

Silicon carbide ( $\mathrm{SiC}$ ), also known as carborundum, is a hard, covalently bonded material produced by the carbothermal reduction of silica using the Acheson process (Acheson, 1895). Approximately $200 \mathrm{SiC}$ poly-types exist due to its periodic stacking in alternate layer arrangements (Sudarshan, 2004). SiC nanoparticles appear in the form of a grayish white powder and cubic morphology with a melting point of $2730{ }^{\circ} \mathrm{C}$ with numerous industrial applications. Thus, $\mathrm{SiC}$ nanoparticles research is an area of intense scientific interest (Mahawish et al., 2017; Attalla et al., 2018).

$\mathrm{SiC}$ nanoparticles hardness, good wear, corrosion resistance, low density and price make them suitable for multiple industries. Initially utilized for grinding and cutting purposes (Cowles and Cowles, 1885; Acheson, 1895). SiC later appeared in ceramic plates, bullet proof vests, glass casting and high performance "ceramic" automobile brake 
discs (Kaufmann et al., 2003; Langhof et al., 2016). Further industrial applications include rubber tire manufacturing, resistance heating element manufacture, and UV protective mirror coatings. SiC nanoparticles are also now used in the copper matrix nanocomposite (Zhang et al., 2004; Ataee-Esfahani et al., 2009; Mula et al., 2011; Zhu et al., 2011).

$\mathrm{SiC}$ nanoparticles widespread use including biomedical industry, necessitates an indepth investigation of their eco-toxicity. To our knowledge, few studies investigated the toxicity of $\mathrm{SiC}$ nanoparticles in the environment; however, several studies focused on the potential health impacts. Several studies report that $\mathrm{SiC}$ nanoparticles are an inert and do not harm lung tissues (Bruch et al., 1993a, b); however, research also suggests that $\mathrm{SiC}$ may have significant cytotoxic and genotoxic effects (Vaughan et al., 1993; Cullen et al., 1997; Akiyama et al., 2007). Vaughan et al. (1993) showed that $\mathrm{SiC}$ was toxic for rats and showed chronic inflammation in necropsies during the study. Another study also found that $\mathrm{SiC}$ accumulates in rat's lungs over the course of a year (Cullen et al., 1997). These findings necessitate further research to determine the toxicity of $\mathrm{SiC}$ to human health, and the potential implications on the environment.

Toxicity depends on the physicochemical characteristics such as particles' size, curvature, shape and surface characteristics charge, functional groups, and free energy (Pourchez et al., 2012). Based on this characterization, some particles generate adverse biological outcomes by causing proteins to unfold, thus resulting in a loss of enzymatic activity. Another pattern is the release of toxic ions in a suspending medium or biological environment (Xia et al., 2008). Thus, several reports have recommended the reevaluation of SiC nanoparticles use (Barillet et al., 2010a, b; Pourchez et al., 2012).

Nematodes as soil organisms were used to evaluate nanoparticles' toxicity (Ma et al., 2009; Cromwell et al., 2014). Nematodes are prevalent and highly distributed in almost every ecological habitat (Hodda, 2011). Some are restricted to a specific geographical environmental condition while others are ubiquitous (Hodda, 2011). The bacterial feeding nematode Caenorhabditis elegans is a well-known multicellular model organism and is used extensively in toxicity assessment studies (Ma et al., 2009; Hunt, 2017). Meloidogyne incognita, a plant parasitic nematode belonging to the root knot nematodes family (RKN), was also challenged with several nanoparticles, such as silver, titanium, and silicon nanoparticles (Ardakani, 2013; Cromwell et al., 2014). The response of $M$. incognita to the three nanoparticles was recorded in laboratory and pot experiments to assess toxicity (Ardakani, 2013). Results showed that $\mathrm{RKN}_{2} \mathrm{~S}$ were highly sensitive to silver nanoparticles while they were less sensitive to titanium and silicon nanoparticles in laboratory. It was also shown that $0.02 \%(\mathrm{~W} / \mathrm{W})$ of silver and titanium nanoparticles totally controlled $\mathrm{RKN}$ in pots.

So far, data are missing regarding the effect of $\mathrm{SiC}$ on soil nematodes and physicochemical characteristics which are factors determining the nanoparticle's toxicity. Therefore, the aim of this study is to characterize the physicochemical properties of SiC nanoparticles and investigate their impact on hatching, mortality and morphology of the nematodes Caenorhabditis elegans and Meloidogyne incognita.

\section{Materials and methods}

\section{Characterization of SiC nanoparticles}

Synthetic SiC nanoparticles were obtained from Hefei Ev Nano Technology Company (China). Stock concentration of $\mathrm{SiC}$ nanoparticles suspensions were prepared $(250 \mathrm{mg} / \mathrm{l})$ in sterile, de-ionized water. In order to obtain stable nanoparticles suspension, an 
ultrasonic processor (UP 200S, Germany) was used to disperse the nanoparticles. In addition, carboxyl methyl cellulose (CMC, BDH chemicals Ltd Poole England) was added (1\% CMC by weight) for dispersion and stabilization of suspension. The acidity $(\mathrm{pH})$ and salinity (measured as electrical conductivity (EC)) were measured for the two concentrations. A half strength concentration was prepared from the stock solution to obtain a suspension of $125 \mathrm{mg} \mathrm{SiC}$ nanoparticles/l with $0.5 \% \mathrm{CMC}$. The two concentrations ( 250 and $125 \mathrm{mg} / \mathrm{l}$ ) were then used in bioassays.

Chemical and physical properties of $\mathrm{SiC}$ nanoparticles were characterized. X-ray powder diffraction (XRD) patterns were recorded using $\mathrm{Cu} \mathrm{K} \alpha$ radiation source by Shimadzu X-ray diffractometer (XRD-6000). The chemical composition of the nanoparticles powder was determined by X-ray fluorescence (XRF) analysis measurements using a sequential X-ray spectrometer (Shimadzu XRF-1800). Nanoparticle surface area and pore size distribution were calculated based on nitrogen adsorption method using Micromeritics' Gemini ${ }^{\circledR}$ VII 2390 Series of surface area and porosity analyzers. SiC nanoparticle morphology was investigated using a Scanning Electron Microscope (SEM) from FEI company- Inspect F50/FEG (Schottky Field Gun) high Vacuum (6e-4 Pa Everhart-Thornley SE detector Solid-State BSED, Netherlands).

\section{Nematode cultures}

\section{Caenorhabditis elegans}

The wild type of $C$. elegans, used in this work, was obtained from the Caenorhabditis Genetics Centre (University of Minnesota). The nematodes were cultured on nematode growth medium (NGM) which consists of $20 \mathrm{~g} / \mathrm{l}$ agar, $2.5 \mathrm{~g} / \mathrm{l}$ peptone, $5 \mathrm{mg} / \mathrm{l}$ cholesterol, $25 \mathrm{mM} \mathrm{KPO}_{4}\left(\mathrm{KH}_{2} \mathrm{PO}_{4}\right.$ and $\left.\mathrm{K}_{2} \mathrm{HPO}_{4}\right)$ buffer, $51 \mathrm{mM} \mathrm{NaCl}$ and $1 \mathrm{mM} \mathrm{MgSO}$. A loopful of the bacteria E. coli strain OP50, obtained from the Caenorhabditis Genetics Centre, was added to the medium as a source of food for the nematode. The bacterial isolate was maintained on Luria-Bertani (LB) medium $(5 \mathrm{~g} / 1$ of yeast extract, $10 \mathrm{~g} / 1$ of tryptone, and $10 \mathrm{~g} / 1 \mathrm{NaCl}$ ). The $C$. elegans culture was maintained periodically and incubated at $24{ }^{\circ} \mathrm{C}$.

To obtain the synchronized eggs or first stage larvae (L1) for bioassays, the nematodes, including the females and the eggs, were washed off the NGM plates with sterile water and placed in a beaker. The nematode suspension was poured on $2 \mathrm{ml}$ eppendorf tubes with a total volume of $1 \mathrm{ml}$. Each $1 \mathrm{ml}$ of nematode suspension was lysed by adding 120 $\mu 1$ of $5 \mathrm{~N}$ sodium hydroxide $(\mathrm{NaOH})$ and $120 \mu \mathrm{l}$ of $6.5 \%$ sodium hypochlorite $(\mathrm{NaOCl})$. This procedure hydrolyzes the adult and juvenile nematodes, but not the eggs. The tubes were vortexed every $30 \mathrm{~s}$ for $5 \mathrm{~min}$. After that the tubes were centrifuged at $6000 \mathrm{rpm}$ for $1 \mathrm{~min}$, supernatant was decanted and the pellets containing the eggs were suspended in 1 $\mathrm{ml}$ sterile water. Tubes were vortexed and centrifuged again to clean the eggs from remaining $\mathrm{NaOH}$ and $\mathrm{NaOCl}$ mixture. The eggs suspension in water was collected and used immediately in the hatching bioassays or eggs were incubated at $24{ }^{\circ} \mathrm{C}$ for $8 \mathrm{~h}$ until L1 hatched and then were used in the toxicity bioassays.

\section{Meloidogyne incognita}

The egg masses and second stage juveniles $\left(\mathrm{J}_{2} \mathrm{~S}\right)$ of the plant parasitic nematode $M$. incognita were used in this assay. The egg masses of $M$. incognita in the hatching assay were handpicked from the roots of infected tomato plants grown in the glass house at the University of Jordan, Amman, Jordan. Egg masses were either directly exposed to the SiC nanoparticles in the hatching bioassay or were incubated in water at $24{ }^{\circ} \mathrm{C}$ until the $\mathrm{J}_{2} \mathrm{~S}$ 
were hatched. The newly hatched $\mathrm{J}_{2} \mathrm{~S}$ were subjected to the $\mathrm{SiC}$ nanoparticles to assess the nematode survival rate.

\section{Nanoparticles suspension}

Eggs or larvae of $C$. elegans were exposed to $1 \mathrm{ml}$ of $\mathrm{SiC}$ nanoparticle suspensions $(688 \mu \mathrm{l}$ of either $\mathrm{SiC}$ nanoparticles concentrations suspended in $\mathrm{CMC}, 62 \mu 10.5 \mathrm{M} \mathrm{KCl}$, $100 \mu 10.5 \mathrm{M} \mathrm{NaCl}$, and $150 \mu \mathrm{l}$ of sterile water contained eggs or larvae). Egg masses and $\mathrm{J}_{2} \mathrm{~S}$ of $M$. incognita were exposed to $5 \mathrm{ml}$ of either concentrations $(3440 \mu \mathrm{l}$ of either concentration of the nanoparticles suspended in $\mathrm{CMC}, 310 \mu 10.5 \mathrm{M} \mathrm{KCl}, 500 \mu 10.5 \mathrm{M}$ $\mathrm{NaCl}$, and $750 \mu \mathrm{l}$ of sterile water contained egg masses or $\mathrm{J}_{2} \mathrm{~s}$ ). All bioassays had two final concentrations of $\mathrm{SiC}$ nanoparticles, 86 and $172 \mathrm{mg} / \mathrm{l}$. The nanoparticles were vortexed and sonicated for $15 \mathrm{~min}$ before the application to prevent the agglomeration of the particles.

\section{Effect of SiC nanoparticles on L1 hatching of C. elegans}

Approximately 400 eggs were exposed to the nanoparticles suspensions in a 24-well tissue culture plate. The $0.5 \% \mathrm{CMC}, 1 \% \mathrm{CMC}$ and water served as controls. Every treatment was replicated three times. Plates were incubated for $24 \mathrm{~h}$ at $24{ }^{\circ} \mathrm{C}$. The treated eggs were checked for L1 hatching after $24 \mathrm{~h}$ using a dissecting light microscope (Nikon, SMZ645) and the percentages of hatching were calculated and tabulated.

\section{Effect of SiC nanoparticles on L1 survival of C. elegans}

In this bioassay, two concentrations of $\mathrm{SiC}$ nanoparticles were used: 86 and $172 \mathrm{mg} / \mathrm{l}$. A total of $50 \mathrm{~L} 1$ were exposed to $1 \mathrm{ml}$ volume of the nanoparticles in a 24 -well tissue culture plate. Treatments contained $0.5 \% \mathrm{CMC}, 1 \% \mathrm{CMC}$ and water only served as controls. Every treatment was replicated three times. Plates were incubated for $6 \mathrm{~h}$ at 24 ${ }^{\circ} \mathrm{C}$. Numbers of dead and live L1 were counted 24 and $36 \mathrm{~h}$ after treatment using inverted binocular compound microscope (MEIJI TECHNO ML VT-T-PC) and the percentages of mortality were calculated and tabulated. The LC50 value was determined by using the polynomial regression curve.

Observations on dead L1 were documented with photos. Lengths and widths of five L1 from each treatment were measured and tabulated.

\section{Effect of SiC nanoparticles on $J_{2}$ S hatching of M. incognita}

In this bioassay, egg masses were exposed to the two concentrations: 86 and $172 \mathrm{mg} / \mathrm{l}$ of $\mathrm{SiC}$ nanoparticles. Similar size egg masses were used in all replicates of all treatments. Every treatment consisted of three egg masses and was replicated three times. $0.5,1 \%$ $\mathrm{CMC}$ and water served as controls. Plates (with a total of $5 \mathrm{ml}$ of SiC nanoparticles) were incubated for seven days at $24{ }^{\circ} \mathrm{C}$. The treated egg masses were checked for $\mathrm{J}_{2} \mathrm{~s}$ hatching after 2, 4 and 7 days of treatment using a dissecting light microscope (Nikon, SMZ645) and the number of hatched $\mathrm{J}_{2} \mathrm{~s}$ after 2, 4, and 7 days were calculated and tabulated.

\section{Effect of SiC nanoparticles on $\mathrm{J}_{2}$ s survival of the M. incognita}

Approximately $50 \mathrm{~J}_{2} \mathrm{~S}$ of $M$. incognita were treated with concentrations of 86 and $172 \mathrm{mg} / \mathrm{l}$ of SiC nanoparticles. The $0.5 \% \mathrm{CMC}, 1 \% \mathrm{CMC}$ and water served as controls. Every treatment was replicated three times. Plates (with $5 \mathrm{ml}$ each) were incubated for 
four days at $24{ }^{\circ} \mathrm{C}$. The numbers of dead and live nematodes were counted using a dissecting light microscope (Nikon, SMZ645) for four consecutive days and the mortality rates were tabulated.

\section{Data analyses}

Data obtained from all bioassays were subjected to analysis of variance and the means were separated using least significant differences (LSD) (Little and Hills., 1974).

\section{Results}

\section{Characterization of SiC nanoparticles}

The X-ray diffractogram patterns revealed that the mineral content is Silicon Carbide (SiC) (Fig. 1). The major peak was at $2 \Theta=35.68^{\circ}, 41.42^{\circ}, 60.01^{\circ}$, and $71.77^{\circ}$. The chemical analyses confirmed that 99.2 wt \% of the nano-powder was $\mathrm{SiC}$ (Fig. 2). The $\mathrm{pH}$ and the electrical conductivity (EC) of the stock solution $(250 \mathrm{mg} / \mathrm{l})$ was 7.8 and $50 \mu \mathrm{S} / \mathrm{cm}$ respectively. $\mathrm{N}_{2}$ sorption isotherm analyses showed that BET surface area was $37.6 \mathrm{~m}^{2} / \mathrm{g}$ and single point adsorption total pore volume of pores less than 126.1853 $\mathrm{nm}$ diameter at $\mathrm{p} / \mathrm{p}^{\circ}=0.984417366$ was $0.124975 \mathrm{~cm}^{3} / \mathrm{g}$. Furthermore, adsorption average pore width was $13.26382 \mathrm{~nm}$.

$\mathrm{SiC}$ nanoparticle morphology was investigated using scanning electron microscopy (SEM). Figure 2 shows that the morphology of the SiC nanoparticles has a semicrystalline shape with incomplete faces. Some edges are angular whereas the others are curved and smooth. The average particle size is $50 \mathrm{~nm} \pm 21.5$.

\section{Effect of SCi nanoparticles on the nematode C. elegans L1 hatching and survival}

To investigate the effect of $\mathrm{SiC}$ on $C$. elegans viability and survival, we exposed the nematode eggs and L1 to 86 and $172 \mathrm{mg} / \mathrm{l}$ of the nanoparticles. Results showed that percentage of hatched L1 was significantly higher when eggs were exposed to SiC nanoparticles compared with controls (Table 1).

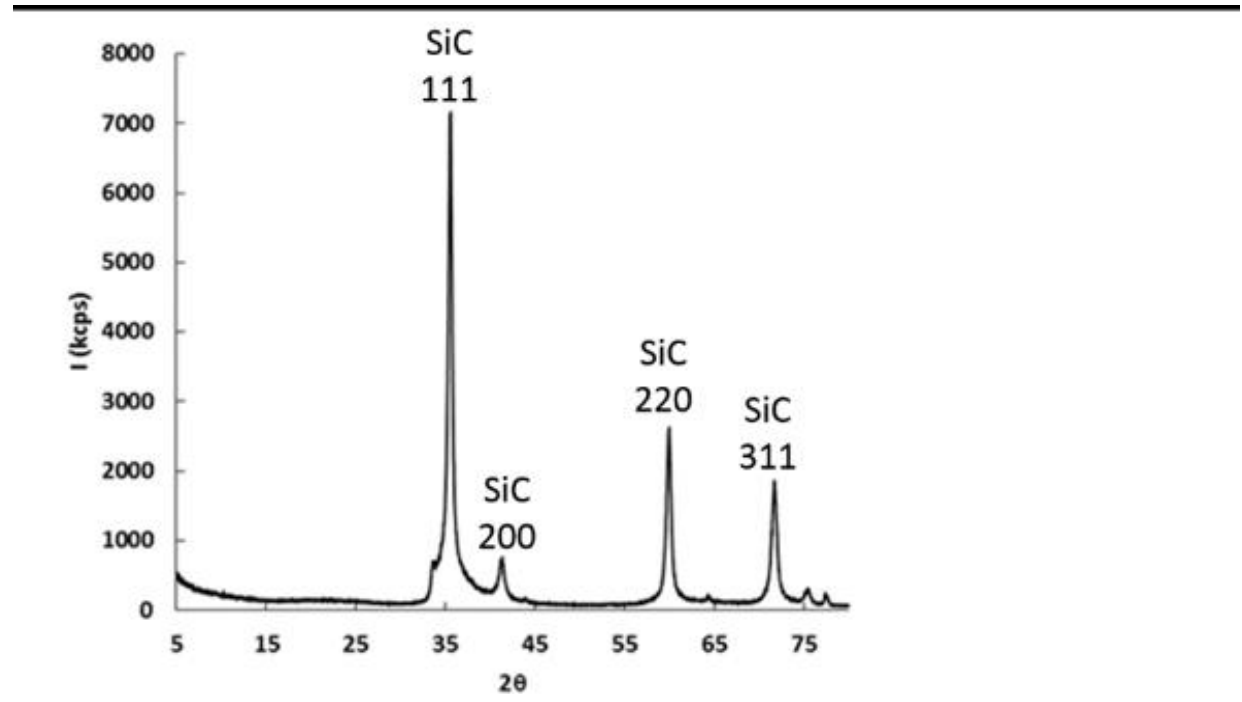

Figure 1. X-ray diffractometer patterns of the used SiC nanoparticles 


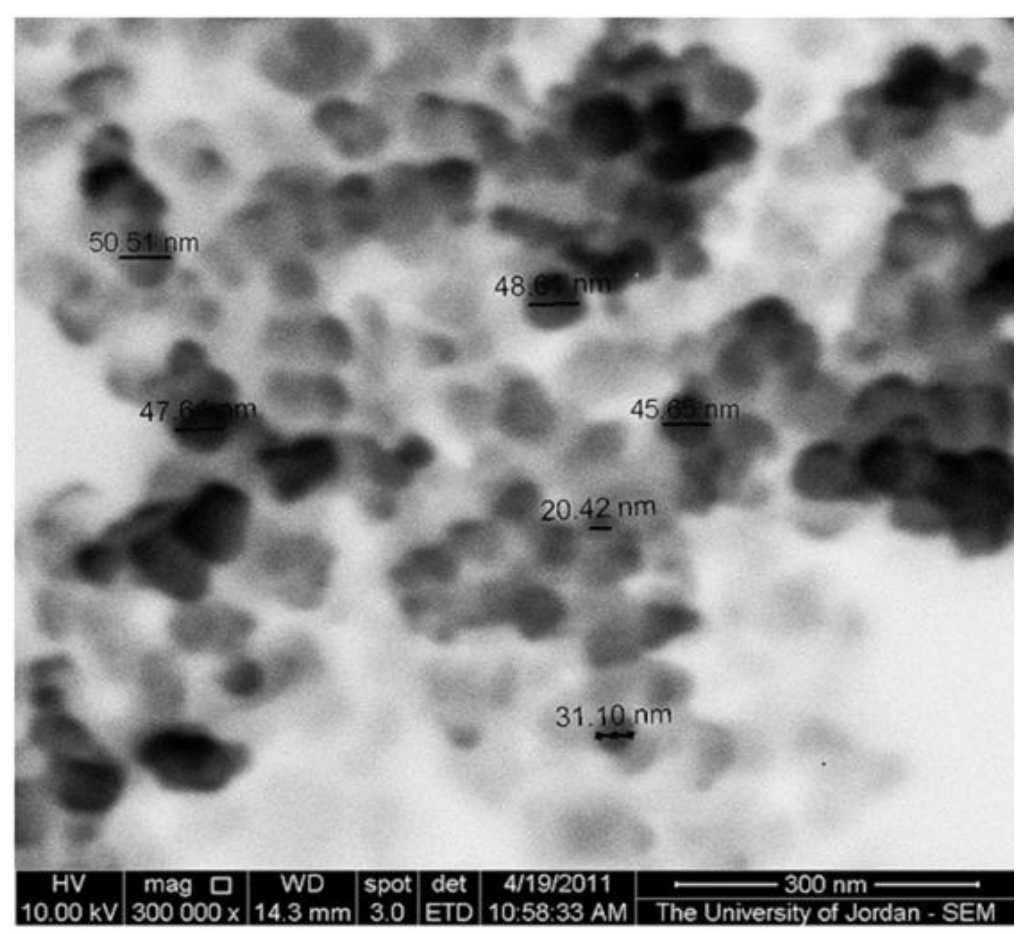

Figure 2. SEM image of SiC nanoparticles

Table 1. Effect of SiC nanoparticles on hatching and mortality of first stage larvae (L1) of a wild type of the nematode Caenorhabditis elegans

\begin{tabular}{c|c|c|c}
\multirow{2}{*}{ Treatment } & \multirow{2}{*}{ Hatching* \% } & \multicolumn{2}{|c}{ Mortality** \% } \\
\cline { 3 - 4 } & & $\mathbf{2 4} \mathbf{~ h}$ & $\mathbf{3 6 ~ h}$ \\
\cline { 3 - 4 } & & $19.3 \mathrm{a} \pm 1.6$ & $69.6 \mathrm{a} \pm 5.3$ \\
\hline SiC nanoparticles $172 \mathrm{mg} / \mathrm{l}$ & $97.5 \mathrm{a} \pm 0.47$ & $17.2 \mathrm{a} \pm 2.8$ & $66.4 \mathrm{a} \pm 8.7$ \\
\hline SiC nanoparticles $86 \mathrm{mg} / 1$ & $98.0 \mathrm{a} \pm 0.32$ & $3.5 \mathrm{~b} \pm 1.2$ & $17.7 \mathrm{~b} \pm 1.5$ \\
\hline CMC 1\% and salts & $94.0 \mathrm{~b} \pm 1.31$ & $2.1 \mathrm{~b} \pm 1.0$ & $15.2 \mathrm{~b} \pm 4.8$ \\
\hline CMC 0.5\% and salts & $94.0 \mathrm{~b} \pm 1.93$ & $2.6 \mathrm{~b} \pm 2.4$ & $9.6 \mathrm{~b} \pm 3.9$ \\
\hline Water only & $95.0 \mathrm{~b} \pm 1.17$ & \multicolumn{2}{|c}{ Exposure time } \\
\hline
\end{tabular}

*The data points represent the means of the three replicates followed by \pm standard deviation, approximately 400 eggs per replicate. Means with the same letter are not significantly different at 0.05 $P$ level

**The data points represent the means of the three replicates, approximately $50 \mathrm{~L} 1$ per replicate. Means with the same letter are not significantly different at $0.05 P$ level

Exposure of L1 individuals to $\mathrm{SiC}$ nanoparticles for $24 \mathrm{~h}$ resulted in a significant $(\mathrm{P}<0.05)$ increase in mortality compared to control treatments. Around 17 and $19 \%$ of $\mathrm{L} 1$ died in $\mathrm{SiC}$ nanoparticle treatments compared to up to $3.5 \% \mathrm{~L} 1$ mortality in controls (Table 1). After $36 \mathrm{~h}$ of exposure to both concentrations of $\mathrm{SiC}$ nanoparticle, the survival of L1 was dramatically decreased and reached 30\% (70\% mortality) and 34\% (66\% mortality) when treated respectively with $172 \mathrm{mg} / \mathrm{l}$ and $86 \mathrm{mg} / \mathrm{l}$; however, the percentage of survived L1 in control treatments were 82, 85 and 90 in $1 \% \mathrm{CMC}, 0.5 \%$ 
$\mathrm{CMC}$ and water controls, respectively. In general, there was no significant difference of survived L1 exposed to $172 \mathrm{mg} / 1$ compared with those exposed to $86 \mathrm{mg} / \mathrm{l} \mathrm{SiC}$ nanoparticles after 24 and $36 \mathrm{~h}$ of exposure (Table 1). Using the regression equation $\left(y=-4 E-05 x^{2}+0.0103 x-2 E-15, R^{2}=1\right)$, the value of LC50 was $65 \mathrm{mg} / \mathrm{l}$ after $36 \mathrm{~h}$ of exposure.

The SiC nanoparticles at both concentrations slightly increased the length and width of L1 compared to salt and water only treatments, but the difference was not significant (Fig. 3).

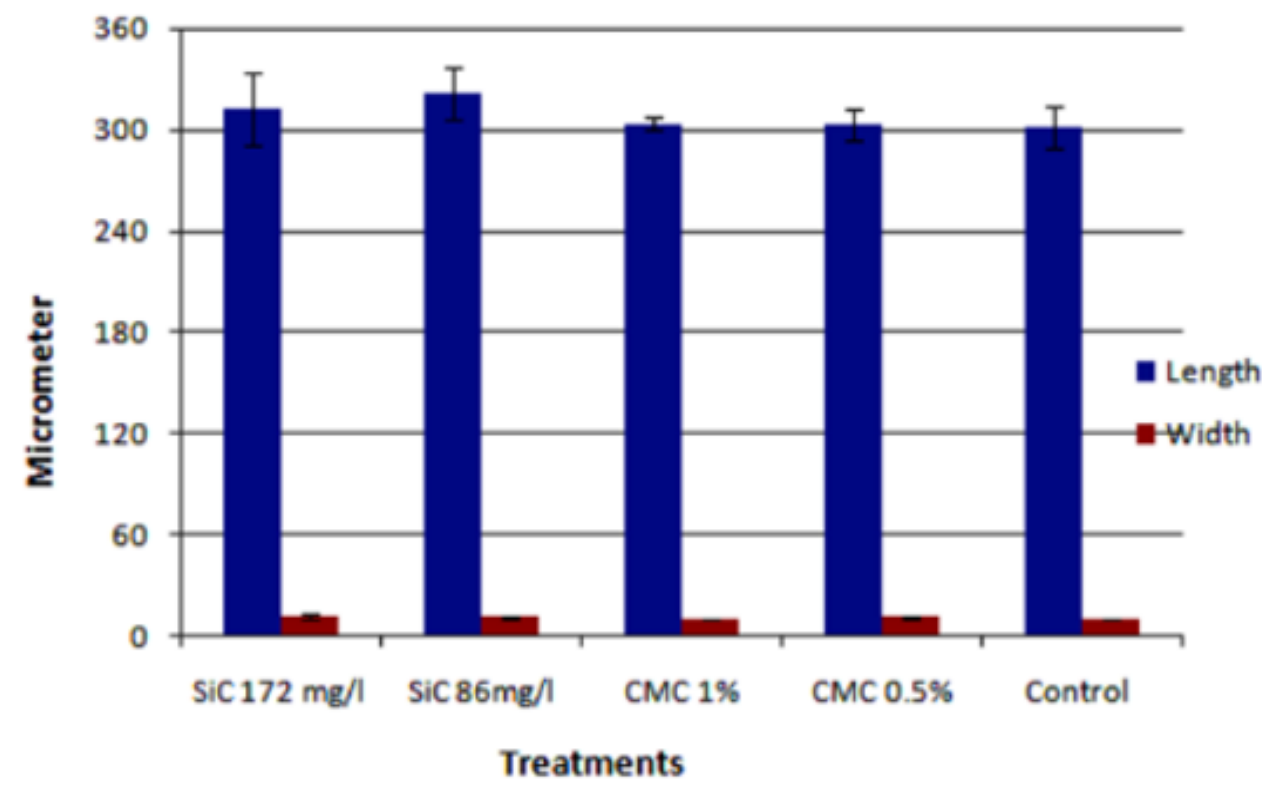

Figure 3. Effect of SiC on length and width of the soil nematode Caenorhabditis elegans. Length and width of the first stage larvae (L1) of the soil nematode Caenorhabditis elegans after $24 \mathrm{~h}$ of exposure to the two concentrations (172 and $86 \mathrm{mg} / \mathrm{l}$ ) of silicon carbide nanoparticles and salts (1\% and 0.5\% CMC) and water controls with E. coli added as a food. The data points and error bars represented the means and standard deviation respectively, of the three replicates, approximately $50 \mathrm{~L} 1$ per replicate

The black color was observed in the internal organs including intestine of the dead L1s that were exposed to the nanoparticles while internal organs were transparent in controls (Fig. 4).

\section{Effect of SiC nanoparticles on $M$. incognita $J_{2}$ s hatching and survival}

To investigate the effect of $\mathrm{SiC}$ on $\mathrm{J}_{2} \mathrm{~S}$ hatching egg masses of $M$. incognita were treated with 86 and $172 \mathrm{mg} / \mathrm{l}$ of the nanoparticles. In all treatments hatching of $\mathrm{J}_{2} \mathrm{~S}$ increased with time. However, treatments with both concentrations of $\mathrm{SiC}$ nanoparticles and the two concentrations of CMC salts resulted in higher number of hatched $\mathrm{J}_{2} \mathrm{~S}$ than those placed in water only at the three monitored times. The use of $86 \mathrm{mg} / \mathrm{l} \mathrm{SiC}$ nanoparticles caused the highest hatching followed by concentration $(172 \mathrm{mg} / \mathrm{l})$ but without significant differences (Table 2). 


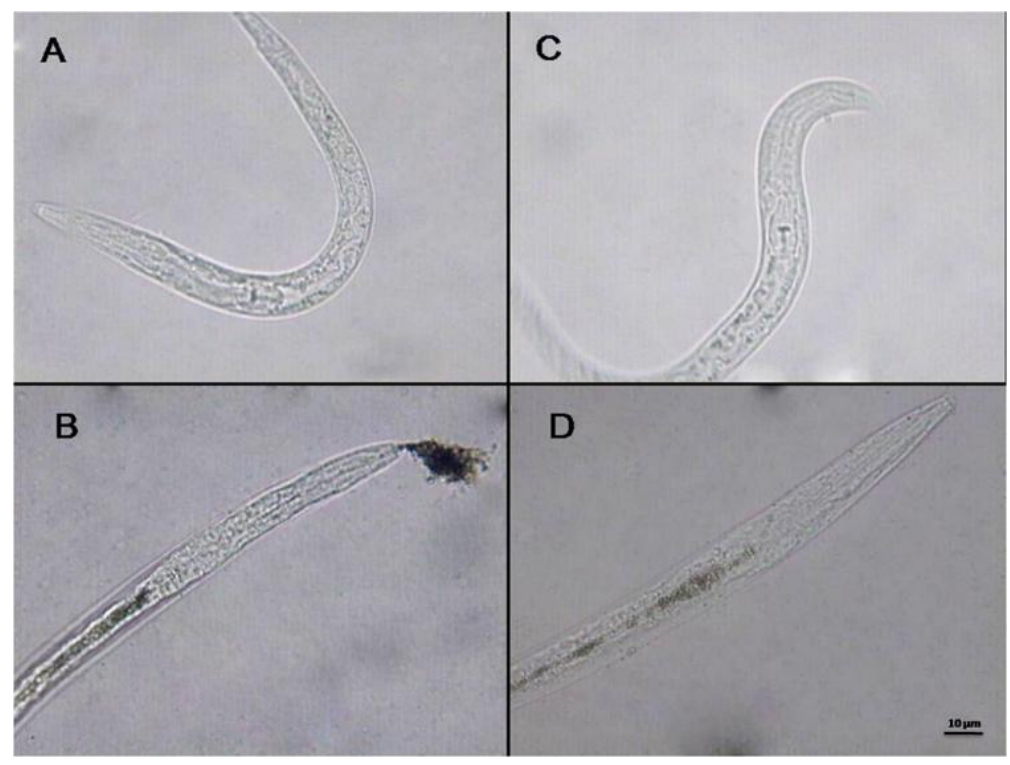

Figure 4. Aggregation of SiC nanoparticles on First stage larvae (L1) of Caenorhabditis elegans. First stage larvae (L1) of Caenorhabditis elegans exposed to (A) $1 \%$ CMC; (B) water only; (C) $86 \mathrm{mg} / \mathrm{l} \mathrm{SiC}$ nanoparticles showing blackening in intestine and aggregation of SiC nanoparticles at anterior extremity; and (D) $172 \mathrm{mg} / \mathrm{l} \mathrm{SiC} \mathrm{nanoparticles} \mathrm{showing} \mathrm{blackening} \mathrm{in}$ the intestine

Table 2. Effect of SiC nanoparticles on hatching of second stage juveniles $\left(J_{2} S\right)$ of the plant parasitic nematode Meloidogyne incognita after the exposure of the eggs for 7 days

\begin{tabular}{c|c|c|c}
\hline \multirow{2}{*}{ Treatment } & \multicolumn{3}{|c}{ No. of hatched J2* } \\
\cline { 2 - 4 } & \multicolumn{3}{|c}{ Exposure for } \\
\cline { 2 - 4 } & 2 days & 4 days & 7 days \\
\hline $\mathrm{SiC}$ nanoparticles $172 \mathrm{mg} / \mathrm{l}$ & $41 \pm 23.8$ & $76 \pm 24$ & $205 \pm 82.6$ \\
\hline $\mathrm{SiC}$ nanoparticles $86 \mathrm{mg} / \mathrm{l}$ & $41 \pm 17.2$ & $90 \pm 35$ & $254 \pm 33.1$ \\
\hline CMC 1\% and salts & $48 \pm 30.4$ & $71 \pm 35.1$ & $192 \pm 93.1$ \\
\hline CMC 0.5\% and salts & $62 \pm 35.9$ & $106 \pm 83.8$ & $185 \pm 133.4$ \\
\hline Water only & $23 \pm 3.51$ & $41 \pm 1.5$ & $104 \pm 10.5$ \\
\hline
\end{tabular}

*The data points represented the means of the three replicates followed by \pm standard deviation, approximately 3 egg masses per replicate. No significant differences at $0.05 P$ level

Similar to the $C$. elegans L1, the two concentrations of SiC nanoparticles did not decrease the $M$. incognita $\mathrm{J}_{2} \mathrm{~S}$ survival. The concentration $(172 \mathrm{mg} / \mathrm{l})$ of $\mathrm{SiC}$ nanoparticles caused a slight reduction in survival of $\mathrm{J}_{2} \mathrm{~s}$ where it decreased to $93 \%(7 \%$ mortality) after one day of exposure and continued to decrease to reach $92 \%$ (8\% mortality) after two days and did not change up to four days of exposure. On the other hand, the low concentration $(86 \mathrm{mg} / \mathrm{l})$ of $\mathrm{SiC}$ nanoparticles did not cause mortality after two days of exposure and caused only $2 \%$ mortality on the third day and stayed steady after the fourth day of exposure (Table 3). Few $\mathrm{J}_{2} \mathrm{~s}$ that were placed in water only died after one day of exposure and no change in the number of live nematodes up to the fourth day of treatment. Similar results were noticed on $\mathrm{J}_{2} \mathrm{~s}$ placed in $0.5 \% \mathrm{CMC}$, while a slight decrease was noted in the number of live $\mathrm{J}_{2} \mathrm{~s}$ treated with $1 \% \mathrm{CMC}$ (Table 3). 
Table 3. Effect of SiC nanoparticles on the survival of second stage juveniles $\left(\mathrm{J}_{2} \mathrm{~S}\right)$ of the plant parasitic nematode Meloidogyne incognita after the exposure of the $J_{2} s$ for 4 days

\begin{tabular}{c|c|c|c|c}
\hline \multirow{2}{*}{ Treatment } & \multicolumn{4}{|c}{ Mortality* \% \pm SD of J2 } \\
\cline { 2 - 5 } & \multicolumn{4}{|c}{ Exposure time } \\
\cline { 2 - 5 } & $\mathbf{1 ~ d a y}$ & $\mathbf{2}$ days & $\mathbf{3}$ days & $\mathbf{4}$ days \\
\hline $\mathrm{SiC}$ nanoparticles $172 \mathrm{mg} / \mathrm{l}$ & $7.03 \pm 6.0$ & $7.89 \mathrm{a} \pm 5.2$ & $7.89 \mathrm{a} \pm 5.2$ & $7.89 \mathrm{a} \pm 5.2$ \\
\hline SiC nanoparticles $86 \mathrm{mg} / \mathrm{l}$ & 0.00 & $0.00 \mathrm{~b}$ & $1.45 \mathrm{~b} \pm 1.3$ & $1.45 \mathrm{~b} \pm 1.3$ \\
\hline CMC $1 \%$ and salts & $1.21 \pm 1.1$ & $1.84 \mathrm{~b} \pm 1.9$ & $1.84 \mathrm{~b} \pm 1.9$ & $1.84 \mathrm{~b} \pm 1.9$ \\
\hline CMC $0.5 \%$ and salts & $0.78 \pm 1.3$ & $0.78 \mathrm{~b} \pm 1.3$ & $0.78 \mathrm{~b} \pm 1.3$ & $0.78 \mathrm{~b} \pm 1.3$ \\
\hline Water only & $0.83 \pm 1.4$ & $0.83 \mathrm{~b} \pm 1.4$ & $0.83 \mathrm{~b} \pm 1.4$ & $0.83 \mathrm{~b} \pm 1.4$ \\
\hline
\end{tabular}

*The data points represented the means of the three replicates followed by \pm standard deviation, approximately $50 \mathrm{~J}_{2} \mathrm{~s}$ per replicate. Means with the same letter are not significantly different at $0.05 P$ level

\section{Discussion}

In this study, we showed the hatchability and the survival of two soil nematodes under the exposure to the SiC nanoparticles. The nematode $C$. elegans was used to test the toxicity of $\mathrm{SiC}$ nanoparticles since basic physiological processes and stress responses are conserved between this nematode and humans (Lee et al., 2007; Hunt, 2017). We used the L1 of $C$. elegans since several reports showed that L1 is more sensitive than both L4 and young adult of $C$. elegans to nanoparticles such as Al nanoparticles and others (Wu et al., 2011).

Hatching of juveniles from eggs of both tested nematodes was not affected and in fact number of hatched juveniles was more in eggs exposed to the $\mathrm{SiC}$ nanoparticles suspension than the controls. Similarly, a complete oocyte development was observed and this development ends with the hatching of the L1 within the parent's body of $C$. elegans after the exposure to silica nanoparticles (Pluskota et al., 2009). This suggests that $\mathrm{SiC}$ and other nanoparticles did not penetrate the eggshell of the eggs and thus hatching was not affected.

The bioassay showed that SiC nanoparticles were lethal to L1 of C. elegans and dead nematodes exhibited black internal organs, indicating that $\mathrm{SiC}$ black nanoparticles were taken up during feeding. This supports results from other studies, which showed that nanoparticles taken by the nematode L1 C. elegans during feeding were translocated to primary and secondary organs, including epithelia cells, intestines and reproductive organs (Pluskota et al., 2009; $\mathrm{Wu}$ et al., 2011). On the contrary, few $\mathbf{J}_{2} \mathrm{~S}$ of the plant parasitic nematode $M$. incognita died when they were exposed to $\mathrm{SiC}$ nanoparticles and lacked the obvious black color in the intestine. This could be attributed to wider mouth of the $\mathrm{L} 1$ of $C$. elegans, which allowed for a larger amount of the $\mathrm{SiC}$ nanoparticles to be taken up during feeding. Additionally, the root knot nematodes, Meloidogyne spp. are obligate sedentary endoparasites and the $\mathrm{J}_{2} \mathrm{~S}$ do not feed when they are found in the soil or in a solution, thus, the uptake of nanoparticles mechanism by these plant parasites should be investigated. We believe that the lethality of the nanoparticles is not due to $\mathrm{pH}$ since nematodes have a wide $\mathrm{pH}$ tolerance that ranged from 3 to 12 (Khanna et al., 1997).

This study showed that the SiC nanoparticles of the size of $50 \mathrm{~nm}$ with LC50 of 65 $\mathrm{mg} / \mathrm{l}$ did not affect hatching of either nematode but did affect the survival of C. elegans. 
Several reports showed that smaller sizes of nanoparticles are more toxic than larger ones (Khare et al., 2011; Park et al., 2011). It was also shown that silver nanoparticles of a size of $20 \mathrm{~nm}$ were more toxic than the larger nanoparticles (80 and $113 \mathrm{~nm}$ ) (Park et al., 2011). Similarly, $\mathrm{TiO}_{2}$ and $\mathrm{ZnO}$ nanoparticles less than $25 \mathrm{~nm}$ were toxic to the nematode C. elegans with LC50 of $77 \mathrm{mg} / \mathrm{l}$ and $0.32 \mathrm{mg} / \mathrm{l}$, respectively (Khare et al., 2011). Whereas $\mathrm{TiO}_{2}$ nanoparticles with a size larger than $25 \mathrm{~nm}$ were non-toxic and LC50 of $2 \mathrm{mg} / \mathrm{l}$ was recorded for $<100 \mathrm{~nm} \mathrm{ZnO}$ nanoparticles. This might explain the contradictory reports that on $\mathrm{SiC}$ nanoparticles' toxicity. However, other characteristics of nanoparticles may affect toxicity and therefore more investigations are needed regarding the comparison of sizes as well as other characteristics.

\section{Conclusion}

The physicochemical characterized $\mathrm{SiC}$ nanoparticles showed a toxic effect on L1 of the multicellular animal, the soil nematode $C$. elegans, and reduced its survival. The dead L1s that were exposed to either 86 or $172 \mathrm{mg} / 1$ of SiC nanoparticles exhibited black internals. In contrast, the two studied concentrations of SiC nanoparticles did not have such an effect on the second stage juveniles $\mathrm{J}_{2} \mathrm{~S}$ of the plant parasitic nematode $M$. incognita. However, these SiC nanoparticles did not have an effect on the eggs of either nematodes, and instead accelerated hatching. Future work should focus on the physical and chemical characteristics of $\mathrm{SiC}$ nanoparticles' toxicity. Additionally, more histological and biochemical studies are needed to assess the mechanism of toxicity.

Acknowledgements. Authors are thankful to Caenorhabditis Genetics Centre (University of Minnesota) for affording the $C$. elegans wild type which was used in this study. Authors are also thankful to Hamdi Mango Center for Scientific Research / The University of Jordan for funding this work and thankful to Mrs Sarah Barnhart for critically reading and editing the manuscript.

\section{REFERENCES}

[1] Acheson, E. G. (1895): Production of artificial crystalline carbonaceous materials. - US Patent 11473.

[2] Akiyama, I., Ogami, A., Oyabu, T., Tanaka, I. (2007): Pulmonary effects and biopersistence of deposited silicon carbide whisker after 1-year inhalation in rats. Inhalation Toxicology 19(2): 141-147.

[3] Ardakani, A. S. (2013): Toxicity of silver, titanium and silicon nanoparticles on the rootknot nematode, Meloidogyne incognita, and growth parameters of tomato. - Nematology 15(6): 1-7. DOI: 10.1163/15685411-00002710.

[4] Ataee-Esfahani, H., Vaezi, M. R., Nikzad, L., Yazdani, B., Sadrnezhaad, S. K. (2009): Influence of $\mathrm{SiC}$ nanoparticles and saccharin on the structure and properties of electrodeposited $\mathrm{Ni}-\mathrm{Fe} / \mathrm{SiC}$ nanocomposite coatings. - Journal of Alloys and Compounds 484: 540-544.

[5] Attalla, R., Ling, C. S. N., Selvaganapathy, P. R. (2018): Silicon carbide nanoparticles as an effective bioadhesive to bond collagen containing composite gel layers for tissue engineering applications. - Advanced Healthcare Materials 7(5). DOI: 10.1002/adhm.201701385.

[6] Barillet, S., Jugan, M., Laye, M., Leconte, Y., Herlin-Boime, N., Reynaud, C., Carrière, M. (2010a): In vitro evaluation of SiC nanoparticles impact on A549 pulmonary cells: Cyto-, genotoxicity and oxidative stress. - Toxicology Letters 198(3): 324-330. 
[7] Barillet, S., Simon-Deckers, A., Herlin-Boime, N., Mayne-L'Hermite, M., Reynaud, C., Cassio, D., Gouget, B., Carriere, M. (2010b): Toxicological consequences of $\mathrm{TiO}_{2}, \mathrm{SiC}$ nanoparticles and multi-walled carbon nanotubes exposure in several mammalian cell types: an in vitro study. - Journal of Nanoparticle Research 12(1): 61-73.

[8] Bruch, J., Rehn, B., Song, H., Gono, E., Malkusch, W. (1993a): Toxicological investigations on silicon-carbide. 1. Inhalation studies. - British Journal of Industrial Medicine 50(9): 797-806.

[9] Bruch, J., Rehn, B., Song, H., Gono, E., Malkusch, W. (1993b): Toxicological investigations on silicon-carbide. 2. In vitro cell tests and long-term injection tests. British Journal of Industrial Medicine 50(9): 807-813.

[10] Cowles, A. H., Cowles, E. H. (1885): Electric smelting furnace. - US Patent: 319945.

[11] Cromwell, W. A., Yang, J., Starr, J. L., Jo, Y. K. (2014): Nematicidal effects of silver nanoparticles on root-knot nematode in bermudagrass. - Journal of Nematology 46(3): 261-266.

[12] Cullen, R. T., Miller, B. G., Davis, J. M. G., Brown, D. M., Donaldson, K. (1997): Shortterm inhalation and in vitro tests as predictors of fiber pathogenicity. - Environmental Health Perspectives 105(5): 1235-1240.

[13] Hodda, M. (2011): Phylum Nematoda Cobb, 1932. In: Zhang, Z.-Q. (Ed.) Animal biodiversity: An outline of higher-level classification and survey of taxonomic richness. Zootaxa 3148: 63-95.

[14] Hunt, P. R. (2017): The C. elegans model in toxicity testing. - Journal of Applied Toxicology 37(1): 50-59. DOI: 10.1002/jat.3357.

[15] Kaufmann, C., Cronin, D., Worswick, M., Pageau, G., Beth, A. (2003): Influence of material properties on the ballistic performance of ceramics for personal body armour. Shock and Vibration 10: 51-58.

[16] Khanna, N., Cressman, C. P., Tatara, C. P., Williams, P. L. (1997): Tolerance of the nematode Caenorhabditis elegans to $\mathrm{pH}$, salinity, and hardness in aquatic media. Archives of Environmental Contamination and Toxicology 32: 110-114.

[17] Khare, P., Sonane, M., Pandey, R., Ali, S., Gupta, K. C., Satish, A. (2011): Adverse effects of $\mathrm{TiO}_{2}$ and $\mathrm{ZnO}$ nanoparticles in soil nematode, Caenorhabditis elegans. Journal of Biomedical Nanotechnology 7(1): 116-117.

[18] Langhof, N., Rabenstein, M., Rosenlöcher, J., Hackenschmidt, R., Krenkel, W., Rieg, F. (2016): Full-ceramic brake systems for high performance friction applications. - Journal of the European Ceramic Society 36(15): 3823-3832. DOI: 10.1016/j.jeurceramsoc.2016.04.040.

[19] Lee, S., Horn, V., Julien, E., Liu, Y., Wysocka, J., Bowerman, B., Hengatner, M. O., Herrr, W. (2007): Epigenetic regulation of histone H3 serine 10 phosporylation status by HCF-1 proteins in C. elegans and mammalian cells. - PloS One e 1213.

[20] Little, T. M., Hills, F. J. (1974): Agricultural Experimentation Design and Analysis. Longman Group, London.

[21] Ma, H., Bertsch, P. M., Glenn, T. C., Kabengi, N. J., Williams, P. L. (2009): Toxicity of manufactured zinc oxide nanoparticles in the nematode Caenorhabditis elegans. Environmental Toxicology and Chemistry 28(6): 1324-1330.

[22] Mahawish, A., Ibrahim, S. I., Jawad, A. H., Othman, F. M. (2017): Effect of adding silicon carbide and titanium carbide nanoparticles on the performance of the cement pastes. - Journal of Civil \& Environmental Engineering 7(4). DOI: 10.4172/2165784X.1000277.

[23] Mula, S., Sahanib, P., Pratiharc, S. K., Mala, S., Kocha, C. C. (2011): Mechanical properties and electrical conductivity of $\mathrm{Cu}-\mathrm{Cr}$ and $\mathrm{Cu}-\mathrm{Cr}-4 \% \mathrm{SiC}$ nanocomposites for thermo-electric applications. - Materials Science and Engineering 258(13-14): 43484356.

[24] Park, M. V. D. Z., Neigh, A. M., Vermeulen, J. P., De La Fonteyne, L. J. J., Verhare, H. W., Briede' van Loveren, H., de Jong, W. H. (2011): The effect of particle size on the 
cytotoxicity, inflammation, developmental toxicity and genotoxicity of silver nanoparticles. - Biomaterials 32(36): 9810-9817.

[25] Pluskota, A., Horzowski, E., Bossinger, O., von Mikecz, A. (2009): In Caenorhabditis elegans nanoparticle-bio-interactions become transparent: Silica-nanoparticles induce reproductive senescence. - PLoS One 4: 1-10.

[26] Pourchez, J., Forest, V., Boumahdi, N., Boudard, D., Tomatis, M., Fubini, B., HerlinBoime, N., Leconte, Y., Guilhot, B., Cottier, M., Grosseau, P. (2012): In vitro cellular responses to silicon carbide nanoparticles: impact of physico-chemical features on proinflammatory and prooxidative effects. - Journal of Nanoparticle Research 14(10): 1143. DOI: 10.1007/s11051-012-1143-7.

[27] Sudarshan, T. (2004): Materials Science and Engineering of Bulk Silicon Carbides. - In: Feng, Z. C. (ed.). SiC Power Materials. New York, Springer.

[28] Vaughan, G. L., Trently, S. A., Wilson, R. B. (1993): Pulmonary response, in vivo, to silicon-carbide whiskers. - Environmental Research 63(2): 191-201.

[29] Wu, S., Lu, J., Rui, Q., Yu, S., Cai, T., Wang, D. (2011): Aluminum nanoparticle exposure in L1 larvae results in more severe lethality toxicity than in L4 larvae or young adults by strengthening the formation of stress response and intestinal lipofuscin accumulation in nematodes. - Environmental Toxicology and Pharmacology 31: 179188.

[30] Xia, T., Kovochich, M., Liong, M., Mädler, L., Gilbert, B., Shi, H., Yeh, J. I., Zink, J. I., Nel, A. E. (2008): Comparison of the mechanism of toxicity of zinc oxide and cerium oxide nanoparticles based on dissolution and oxidative stress properties. - ACS Nano 2: 2121-2134.

[31] Zhang, R., Gao, L., Guoa, J. (2004): Effect of $\mathrm{Cu}_{2} \mathrm{O}$ on the fabrication of $\mathrm{SiCp} / \mathrm{Cu}$ nanocomposites using coated particles and conventional sintering. - Compos Part $\mathrm{A}$ Applied Science and Manufacturing 35(11): 1301-1305.

[32] Zhu, S. L., Tang, L., Cui, Z. D., Wei, Q., Yang, X. J. (2011): Preparation of coppercoated $\beta$-SiC nanoparticles by electroless plating. - Surface and Coatings Technology 205: 2985-2988. 